\title{
Public Health and Bioethics, Reflections on Sars-Cov-2 (Covid-19) in Colombia
}

Salud Pública y Bioética, Reflexiones sobre Sars-Cov-2 (Covid-19) en

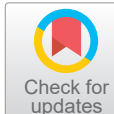
Colombia

Saúde Pública e Bioética, Reflexões sobre Sars-Cov-2 (Covid-19) na Colômbia

How to cite this article: Vélez-Álvarez Consuelo, Betancurth Loaiza Diana Paola, Holguín Zuluaga Juan Alejandro. Public Health and Bioethics, Reflections on Sars-Cov-2 (Covid-19) in Colombia. Revista Cuidarte. 2021;12(1):e1369. http://dx.doi.org/10.15649/cuidarte.1369

Revista Cuidarte

dey Cuid. Ene. - Abril. 2021; 12(1): e1369

http://dx.doi.org/10.15649/cuidarte.1369

E-ISSN: 2346-3414

(1) Consuelo Vélez Álvarez

(1) Diana Paola Betancurth Loaiza ${ }^{2}$

(1) Juan Alejandro Holguín Zuluaga ${ }^{3}$

1 Universidad de Caldas, Manizales Colombia. E-mail:

consuelo.velez@ucaldas.edu.co

2 Universidad de Caldas, Manizales Colombia. E-mail:

diana.betancurth@ucaldas.edu. co

3 Universidad de Caldas, Manizales Colombia. E-mail:

juan.holguin@ucaldas.edu.co
Dear editor,

The quick spread of the COVID-19 disease has generated the establishment of coordination mechanisms, control and lengthy actions by actors and/or agents, which has triggered border barriers between communities and people to curb the contagion. This situation has also produced fear of infection and a survival instinct that has inevitably altered the perception of the other, which is viewed with mistrust when configuring itself as a potentially infectious person; in extreme cases there is even discrimination or exclusion.

However, this should not affect collaboration to fight at all levels: governments, public and private sectors, civil society, international and regional organizations, while overcoming selfishness and segregation. So much so that the ethical ideal must transcend political borders, geographical limits and cultural differences, so that the So much so that the ethical ideal must transcend political borders, geographical limits and cultural differences, so that the focus is on the common needs of people and the joint responsibility to dialogue about concrete solutions to overcome the difficult situation. In other words, there is a need for constructive crossdisciplinary meetings between governmental and scientific actors that help overcome the crisis.

needs of people and the joint responsibility to dialogue about concrete solutions to overcome the difficult situation. In other

Receibed: July 14th, 2020

Accepted: September 10th, 2020

Published: November 13th, 2020 $\nabla *$ Correspondencia

Consuelo Vélez Álvarez

E-mail:consuelo.velez@ucaldas.edu.co 
words, there is a need for constructive cross-disciplinary meetings between governmental and scientific actors that help overcome the crisis.

That is why in Colombia, as in other countries, there is concern about policies based on epidemiological data analysis of past events, when the behavior of the contagion may be heterogeneous according to the territories. This, without a doubt, can compromise the wellbeing of the population in a panorama of uncertainty and in the evolution of the virus, which requires ethical and contextual reflections on decisions that can be potentially negative in unsafe conditions, as insufficient resources for care in health (e.g. beds in intensive care units).

Indeed, the pandemic made evident the health systems fragility in the world and Colombia is no exception. The efficient management of scarce resources and the strengthening of public health must be a priority matter for the government; under this scenario, ethical principles are unwavering, they must be adjusted to exceptional circumstances, in which scientific integrity protects them for the common good. At the same time, they must bring with them respect for human rights, privacy and autonomy to handle themselves with caution when confronted with values of security and protection. In this important challenge, the Colombian government has taken measures that can be classified into three lines:
The efficient management of scarce resources and the strengthening of public health must be a priority matter for the government; under this scenario, ethical principles are unwavering, they must be adjusted to exceptional circumstances, in which scientific integrity protects them for the common good

1. Sanitary and health emergency measures.

2. Social, economic and ecological emergency measures.

3. Public order and other ordinary measures.

There are close relationships between them and in each group of measures and standards, the aim is to improve and take the most appropriate actions to handle the situation cleverly. The end: the greatest benefit to society when carrying out intersectoral work in areas such as education, culture, economy and health ${ }^{1}$, among others.

The field of public health is one of collective action, both by the State and by civil society. It deals with the health problems of individuals and populations, seeking to protect and elevate health conditions with the planning and design of educational strategies, health promotion, disease prevention and diagnosis services organization, treatment and rehabilitation. The concept assumes responsibilities that include collective interventions and access to quality and ethical health care services, which is why it constitutes an interdisciplinary social practice ${ }^{2}$. For this reason, it is the responsibility of public health ethics to design and apply measures for the surveillance and perfection of the population health. Furthermore, it goes beyond healthcare by addressing structural conditions that facilitate or hinder the goal of building healthy societies ${ }^{3}$.

On the other hand, COVID-19 is an emerging acute infectious disease that has reached vertiginous proportions that require ethically acceptable reflections and collective responses ${ }^{4}$. Hence, it is a challenge for public health, the economy and individual and community wellbeing, therefore, it threatens life and forces isolation and confinement. However, at the same time, it highlights the family and the environment importance, as well as the need for health services that are appropriate to the situation. 
Ethics has taken center stage in the mission of the World Health Organization (WHO) by protecting and promoting health through the formulation of policies that combine ethical and scientifically based principles as one of the six basic functions ${ }^{5}$. Consequently, in the COVID-19 pandemic framework, and from a global perspective, some of the essential issues of public health ethics are the following:

Inequalities in health status, access to care and benefits of medical research: social justice is inherent to public health, there is a duty to seek better levels of health for vulnerable populations and thus reduce inequities, for example, it is necessary to make value judgments to allocate state resources that benefit the most disadvantaged against to interventions that benefit a few.

Infectious diseases threat response: government actions of all kinds to curb the spread of infectious diseases involve complex questions and actions about the usefulness of limiting individual freedoms to safeguard the common welfare. An example of this are the isolation and quarantine caused by the current pandemic situation.

International cooperation in surveillance and health monitoring: the guidelines of the International Health Regulations make it possible to see the commitment of the countries to act together in the face of public health emergencies, determine the scope of the obligations collectively and define how they should be fulfilled. One way or another, this will pose huge ethical dilemmas to be solved, under the premise that collective benefits prevail over individual ones ${ }^{6}$.

It cannot be ignored that isolation and quarantine measures and their results are much more difficult for the most vulnerable populations. Given this, the government has implemented support strategies to counter the higher incidence of mental illness, mitigate the increase in domestic and gender violence cases and subsidize the "poor population" who depend economically on informal activities. However, this is a pandemic that strongly reflects the inequities and social inequalities of Colombian families and the invisible stories as a result

This is a pandemic that strongly reflects the inequities and social inequalities of Colombian families and the invisible stories as a result of the extreme injustices that the countries experience, especially the socalled "third worlds". of the extreme injustices that the countries experience, especially the so-called "third worlds".

On the other hand, when it is necessary to prioritize patients in a context of scarce resources, the need according to the clinical condition and the most effective treatment available should be the criteria to be considered. The procedures for making these decisions have been systematized so that they are transparent and ethical.

The official information from the government, scientists and the media has generally been simple, clear, precise, complete and timely. So, that it is understood by society, regardless of age or level of education. It can be understood that no panic has been generated, but the risk has not been minimized either. In contrast, lightness on social networks, misinformation, disqualification and panic-generating messages affect mental health and awaken survival instincts that undermine preventive efforts, so their presence should not be tolerated.

During the pandemic, the right to health can only be guaranteed through the health duty, it is everyone's responsibility to comply with the rules that protect not only individuals, but especially the community. Therefore, abiding by the instructions and recommendations of the 
authorities, promoting respect and dialogue in relations of coexistence, are essential to mitigate the pandemic, as well as to avoid meetings and celebrations or unnecessary mobilizations in the city or between cities and municipalities.

Finally, the acts of corruption and inadequate use of public resources are repugnant, condemnable, and unethical acts, deeply affect society; they cannot be tolerated and must be openly denounced7. By way of conclusion, it is worth saying that the way of life has completely changed, work and educational activities, places of recreation, shops and social life with family and friends suddenly stopped. In any case, there is a desire to overcome the multiple challenges that the pandemic implies for public health, the economy and individual and community well-being, so that society must mutually support, be in solidarity, respect those who think differently, be empathetic and put yourself in the place of others. Solidarity, justice in the Therefore it is the moment when public health and bioethics come together as a dyad to think in terms not only biological, but social and in this way, give a comprehensive response to the needs of society in the context of the current situation, in which the distant becomes close and the unattainable must approach the reality we live in. distribution of the scarce existing resources and honesty must prevail, therefore it is the moment when public health and bioethics come together as a dyad to think in terms not only biological, but social and in this way, give a comprehensive response to the needs of society in the context of the current situation, in which the distant becomes close and the unattainable must approach the reality we live in.

Conflict of interest: The authors declare that there is no conflict of interest

\section{References}

1. Colombia. Ministerio de Salud y Protección Social. Documentos administrativos Covid-19. Consulta: Junio 20, 2020. Disponible en: https://www.minsalud.gov.co/salud/publica/PET/ Paginas/Documentos-Administrativos-covid-19.aspx

2. Muñoz, F., López, D., Halverson, P., Guerra de Macedo, C., Hanna, W., Larrieu, M., Ubilla, S., y Zeballos, L. Las funciones esenciales de la salud pública: un tema emergente en las reformas del sector de la salud. Rev Panam Salud Publica/Pan Am J Public Health. 2000;8(1):1-9. https://doi.org/10.1590/S1020-49892000000700017

3. Organización Mundial de la Salud (OMS). Contribución de la ética a la salud pública. Boletín de la Organización Mundial de la Salud. Recopilación de artículos. 2008;86:577-656.

4. Organización de las Naciones Unidas para la Educación, la Ciencia y la Cultura (Unesco). Declaración sobre el COVID-19: consideraciones éticas desde una perspectiva global Declaración del Comité Internacional de Bioética de la UNESCO (IBC) y la Comisión Mundial de la UNESCO sobre la Ética del Conocimiento y Tecnología Científica (COMEST). Centro Unesco Andalucia. 2020;12:1-10

5. World Health Organization. Engaging for health : eleventh general programme of work, 2006-2015 : a global health agenda : executive summary. Consulta: Junio 23, 2020. Disponible en: https://apps.who.int/iris/handle/10665/69403

6. World Health Organization. WHA58.3 Revision of the International Health Regulations. Consulta: Junio 20, 2020. Disponible en: https://www.who.int/ipcs/publications/wha/ihr_resolution.pdf

7. Colombia. Ministerio de Salud y Protección Social. Valores éticos frente al Coronavirus. Consulta: Junio 24, 2020. Disponible en: https://www.minsalud.gov.co/Paginas/Valores-eticos-frente-al-coronavirus.aspx 